\title{
Iconisation, attribution and branding in orthography
}

Mark Sebba, Lancaster University

Published in: Written Language \& Literacy 18:2, 208-227.

http://dx.doi.org/10.1075/wll.18.2.02seb

\begin{abstract}
This paper discusses three processes relating to the social meaning of scripts and orthographies, all of which are potentially mediated by the role of script-as-image. One of these processes, iconisation, was introduced to the field by Irvine and Gal (2000) and is widely known. Attribution is a process which precedes iconisation, whereby a group of people associate a linguistic feature or language-related practice with a group of people who (supposedly) use that feature or engage in that practice. Orthographic branding involves a specific visual/graphical element of written language such as an alphabetic character. Through 'branding,' this element becomes an emblem of a group of people who use the element in question in their writing practices. Branding may involve iconisation, but the processes are distinct. This paper describes and distinguishes the three processes and provides examples from different languages and user communities.
\end{abstract}

Keywords: iconisation, orthography, script, literacy, multimodality

\section{Introduction}

Without an image, there is no written language. Unlike spoken language, which is quickly lost unless steps are taken to audio-record it, (the characteristic which Hockett (1966:7) calls 'rapid fading'), written language involves creating an image - either by making lasting marks on a surface, or in a digital form - which may be seen and remembered. These images are what enable us to recognise, and thus read, the characters used in writing a language, but the image may be recalled and interpreted even by a viewer who does not know the language in question.

Each character in an alphabetic or syllabic system usually has a distinctive image, but combinations of characters such as words and bound morphemes, and sub-parts of characters - for example, diacritics - also have characteristic images. Although they do not directly carry semantic meaning, these images may nevertheless provide contextualisation for the message they compose (for example, a word written in red characters may be interpreted as 
urgent or as a warning) and may in addition carry social meaning. The dual nature of the characters in writing systems - as elements of a linguistic system and as images - has of course been understood and used as a creative resource by artists and typographers for millennia. It seems to have been of relatively little interest to linguists, however, at least until recently.

In this paper I shall discuss three processes in which the social meaning of scripts and orthographies is mediated by the role of script-as-image. One of these processes, iconisation, was introduced to the field by Irvine and Gal (2000) and is already well known to researchers in the field of orthography studies. Another process, which I here call attribution, is a necessary prelude to iconisation, and involves the perceived association of elements or practices with a group of people. The third process, branding, is the attribution of a graphical element - such as a letter of the alphabet or a diacritic mark - to a group, with or without iconisation. In the rest of this paper, I shall define and discuss these processes and the relationships between them, and give case studies as examples.

\section{Attribution}

Attribution is a term which I will use in this paper for a process whereby one group of people, A, make an association between a linguistic feature or language-related practice, $\mathrm{X}$, and a group of people, B, who (supposedly) use that feature or engage in that practice. Use of the feature or practice in question can then be said to be attributed to the supposed user group B by the group A. In the tradition of Le Page and Tabouret-Keller (1985) we can see these groups not as fixed and based on 'factual' genetic or geographical boundaries but dynamic, discursively constructed and predicated on perceptions, preferences and beliefs.The practices and linguistic features attributed to the groups may be social constructs as well, but in some cases they may have a more objective existence; for example, they could involve specific words or expressions, or characters within a writing system.

Attribution is related to Le Page's notion of projection: 'as the individual speaks he is seen as always using language with reference to the inner models of the universe he has constructed for himself; he projects in words images of that universe [...] [while] inviting others to share his view of the universe' (Le Page and Tabouret-Keller 1985: 115). Le Page’s 'inner models of the universe' are individual models which ultimately become collective when enough others share the same 'view of the universe' which they have 'projected in words'. The notion of attribution used here likewise involves a discursively constructed model of the 
universe in which a perceived group is perceived to engage in a particular perceived linguistic behaviour. Although this model may differ from other people's models of supposedly the same universe, and may even be in conflict with ascertainable 'facts', it may be based at least partly on real-world experience of the practices of the self or other.

A mixture of limited personal experience, collective tradition and discursively constructed 'knowledge' about language could be said to be the basis for much of folk linguistics (Preston and Niedzielski 2000). The study of folk linguistics is certainly concerned with questions of attribution, in the sense of 'who thinks who says what', but its focus is different from that of the present paper in three main ways. (1) The most relevant area of research within folk linguistics, namely perceptual dialectology, is mainly interested in spoken language rather than written representations of language; (2) perceptual dialectology is concerned mainly with perceived dialects and boundaries within one 'language' or Dachsprache, meaning that it does not give much attention to folk beliefs about the practices of speakers of other languages; (3) folk linguistics research has studied in detail the relationship between speech forms and the groups (defined e.g. by social class, gender, ethnicity or geography) who are believed by 'folk' to use them, but has paid less attention to the social process by which the forms in question become associated with (in our terms, 'attributed to') those groups.

By contrast, these three areas would be of central interest in a study of orthographic attribution. To take an example which is well-known in the literature of orthography research, linguists supporting vernacular literacy campaigns in Haiti in the 1940s introduced an orthography based on phonemic principles, which used letter-sound correspondences based on international, rather than French, usage. According to Schieffelin and Doucet (1994: 191) this was strongly opposed by some of the educated elite, including linguists, because of the break with the French orthographic tradition. In particular $\langle w\rangle,\langle y\rangle$ and $\langle k\rangle$ were resisted by some as being ‘too American’ and characterized as ‘Anglo-Saxon’ letters.

In this case, the practice of using the letters $\langle w\rangle,\langle y\rangle$ and $\langle k\rangle$ was attributed by a subsection of Haitians to the 'Americans' or 'Anglo-Saxons'. Notice first of all that this attribution appears to have been a discursive process, carried out via public discussions, letters to the press, scholarly articles etc. Secondly, it involves a perceived group, whether 'Americans' or 'Anglo-Saxons', who are constructed as behaving homogenously in at least this respect. Thirdly, this group is disjoint from the group who are attributing the behaviour to 
them, who are Haitian and therefore making judgements about the practices of a group whom they may know more or less well, but in any case as outsiders rather than insiders. Fourthly, this process of attribution also involves an act of erasure (Irvine and Gal 2000), since the fact is overlooked that one of these letters, $\langle y>$, is a letter which occurs commonly in native French words and is therefore at least as 'French' as it is 'American' ( $<\mathrm{w}>$ is also used in French, but mainly in personal and place names in the northern parts of France and Belgium; $<\mathrm{k}>$ is genuinely a rare letter in traditional French orthography, although it has become more common recently in digital media.) Fifthly, the visual mode - 'script-as-image' - is central to the attribution. Detractors of the orthography refer to its 'weird' and 'Anglo-Saxon' look, the result of using these specific letters.

Attribution, defined as it is here, is close in some respects to Agha's widely used concept of enregisterment, which he describes as a process 'through which a linguistic repertoire becomes differentiable within a language as a socially recognized register of forms' (Agha 2007: 190) and 'the process whereby one register formation comes to be distinguished from other modes of activity, including other registers, and endowed with specific performable values (Agha 2007: 4). In particular, attribution and enregisterment are both processes, and both involve the association of a linguistic object (a category, behaviour, or set of behaviours) with a social group. Agha terms an enregistered emblem 'a thing/diacritic [which] is widely recognized as an emblem - when many people view it as marking the same social persona' (Agha 2007: 235).

Despite these similarities, attribution and enregisterment are not the same thing. Although Agha discusses 'cases where processes of enregisterment yield semiotic formations that do not correspond to discourse registers as classically understood' (2007: 81), in fact nearly all the discussion of enregisterment is exemplified by registers, 'repertoire[s] of performable signs' (2007: 80), within one language as identified by its users: 'the registers of a language have a differentiable existence only insofar as and as long as they are treated by language users as functionally recognized partitions within the total inventory of its expressive means' (Agha 2007: 169). Furthermore, although Agha does mention written registers, spoken language is taken as fundamental: 'processes of enregisterment involve a gradual sedimentation of habits of speech perception and production across particular social domains of persons (Agha 2007: 229). There are certainly cases where attribution and enregisterment may coincide, for example, where certain orthographic practices become associated with subcultural groups and become an identifiable 'register'. Examples might be the distinctive 
orthographic practices of German fanzine writers (Androutsopoulos the Spanish countercultural practice of writing $<\mathrm{k}>$ for $<\mathrm{qu}>$ (Sebba 2007: 3ff). But in other cases attribution is cross-linguistic and involves the association of practices with users of a different language altogether, making it difficult to conceive in terms of 'registers' as Agha does, as 'partitions' within the expressive range of a language.

\section{Iconisation}

Iconisation, fractal recursivity and erasure (Irvine and Gal 2000: 37) are three semiotic processes which are central to Irvine and Gal's model of the ideologies of linguistic differentiation, which they define as 'the ideas with which participants and observers frame their understanding of linguistic varieties and map those understandings on to people, events, and activities'. Among these processes, Iconisation involves 'a transformation of the sign relationship between linguistic features (or varieties) and the social image with which they are linked' (Irvine and Gal 2000: 37). In Irvine and Gal's formulation, the agency of this transformation is not explicit - whether it lies with the 'participants' or the 'observers' of the process or with both. Once the transformation has taken place, 'linguistic features that index social groups or activities appear to be iconic representations of them, as if a linguistic feature somehow depicted or displayed a social group's inherent nature or essence.' Although the case studies used by Irvine and Gal in their classic paper (2000) do not centrally involve scripts or orthographies, subsequent research has identified many instances of iconisation involving both ${ }^{1}$, several of which will be discussed later in this paper. An example of a ‘classic case of iconisation’ (Androutsopoulos 2010) involving orthographic representation would be Kanak Sprak, a language used by characters in Feridun Zaimoglu's literary works who belong to the second generation of Turkish migrants in Germany. According to Androutsopoulos (2010: 187) the distance between Kanak Sprak and 'normal' German (including the nonstandard spelling Sprak for standard Sprache, 'language’) iconically

\footnotetext{
${ }^{1}$ There are also references to icon and iconicity in orthography research which predate Irvine and Gal's paper, but it is not clear that they refer to exactly the same phenomenon. So Bird (2001: 148) writes about the barred-u symbol 'iconifying' the cultural unity of the Bamileke group of Grasslands languages. Schieffelin and Doucet (1994: 192) remark that 'the recent arguments regarding the implementation of the reform of the French orthography are a good example of how a country can stick to its orthographic icons as symbols of its identity', giving in a footnote the example of the circumflex on certain letters. In these examples icon seems to be used in a more general way, and not to imply the 'transformation of the sign relationship’ which is a requirement for iconisation in Irvine and Gal’s sense.
} 
represents the distance of its speakers from German society. The 'deviant' German thus becomes an iconic representation of a 'deviant' social group. Other cases of iconisation involving scripts and/or orthographies, some of which will be discussed in more detail in this paper, include, Schieffelin and Doucet 1994, Urla 1995, Thomas 2007, Sebba 2003, Ahmad 2012, Spitzmüller 2012 and Vosters et al. 2012.

\section{Branding}

The last of the three processes to be discussed here is branding. The currently predominant meaning of 'branding' highlights the strategic promotion of the branded product or concept, its distinctiveness or 'unique selling point'. In this contemporary meaning, 'branding' may include visual images (in particular, logos) but refers more broadly to a process of identity creation by verbal and/or visual discursive means ${ }^{2}$.

Strategic uses of orthography for commercial purposes have long been recognised by researchers (see, for example, Davies 1987). In this paper 'branding' is used more broadly, to refer to a process whereby a specific visual/graphical element of written language such as an alphabetic character becomes emblematic of a group of people who use that element in their writing practices. Branding necessarily involves selection of a salient element from the relatively large repertoire of visual signs which are used in a script or orthography; this element then comes to be emblematic of the group who use it.

Branding may be done by the users themselves, who establish the item in question as their 'brand', or it may be done by an outgroup. An example of each type is provided by the graphology of German, as described by Spitzmüller (2012). The letter $<\beta>$ 'Eszett, s-z', which is currently used only in German, was officially made redundant by the German spelling reforms of the late 1990s (Johnson 2005). Since that time, $<\beta>$ 'has not only been deliberately used by opponents of the reform as a symbol for "correct” or "proper” German, but the recipients who perceive this usage have also been invited to join the club of "proper Germans" - the circle of "those who know”' (Spitzmüller 2012: 262) ${ }^{3}$. Thus $<\beta>$ has become a 'brand' for the self-styled 'proper Germans,' and will be recognizable as such by both the users of $\langle\beta>$, and the non-users, those who abide by the reforms. However, to non-users of

\footnotetext{
${ }^{2}$ An earlier meaning of 'branding' was to burn ('brand') an image - typically, a letter of the alphabet - on animals, as a way of identifying whose herd they belonged to. The alphabetic association seems appropriate here.

${ }^{3}$ Spitzmüller describes this a case of iconisation (2012: 262). This is not incompatible with it also being a case of branding; not all instances of branding involve iconisation, but some do.
} 
German in the rest of the world, who have no sense of what might indicate a more or less 'authentic' user of written German, $<\beta>$ has no particular significance.

By contrast, the German umlaut or diaresis, as in $<\ddot{a}>$, $<\ddot{o}>$ and $<\ddot{\mathrm{u}}>$, is, for all users of written German, just a standard part of the practice of writing the language. Although it can be substituted by $<\mathrm{e}>$ to produce the alternative representations $<\mathrm{ae}>,<\mathrm{oe}>$ and $<\mathrm{ue}>$, choosing to write the diaresis does not make the writer seem more 'proper' or 'correct' in the eyes of other German users. Yet for non-users of German, the umlauted characters are salient and potentially significant. As Spitzmüller points out (2012: 261), 'In English texts, for instance, where these characters are not bound to the graphematic system and where they are thus highly perceptible, they usually serve as signs of foreignness, or, more specifically, as signs of 'Germanness' and whatever ideology is bound to this.' Thus for non-Germans, the umlaut 'brands' the texts it accompanies as German and associates them with perceived 'Germanness'. In this way it comes close to the commercial sense of 'branding,' as heavy metal bands from non-German speaking countries (e.g. Motörhead and Mötley Crüe) use the umlauts to index their 'Gothic' character, despite the umlauts having no linguistic function in the names of the bands (Spitzmüller 2007: 402).

\section{The relationship between iconisation, attribution and branding}

Attribution in the sense in which it is used here, is a process in which a particular linguistic practice is constructed as characteristic of a (perceived) group. Attribution seems to be a prerequisite for iconisation, as according to Irvine and Gal (2000: 37), the latter requires ‘a transformation of the sign relationship between linguistic features (or varieties) and the social image with which they are linked'. So there must be a pre-existing association between linguistic features and a 'social image', or in our terms, the attribution of certain linguistic practices to a group. Iconisation can be said to have taken place when the sign relationship has been transformed into an iconic one, so that the linguistic features are seen not just to be a normal part of the linguistic practice of the group, but to be 'iconic representations of them, as if a linguistic feature somehow depicted or displayed a social group's inherent nature or essence' (Irvine and Gal 2000: 37). Ahmad (2012) gives a clear example of how this process was applied to the Urdu script in the linguistic construction of Hindu identity in the late 19th century in North India: 'It was argued that the fraudulent character of the script and language 
stemmed from their orthographic shortcomings ${ }^{4}$ [...] This "promiscuous" nature of the script was then held responsible for causing fraud and forgery’ (Ahmad 2012: 116). It was then possible to 'project this alleged defect of the Urdu language and script onto Muslims' (Ahmad 2012: 117): fraudulent script, fraudulent people.

Branding likewise involves the attribution of a linguistic feature, in this case by definition a graphical one, to a group. Attribution is therefore a prerequisite for branding too, but branding does not necessarily involve iconisation. An example of branding without apparent iconisation is provided by the case of a diacritic mark, the haček (literally 'little hook' in Czech), which goes above certain letters, typically $<\breve{\mathrm{c}}><\breve{\mathrm{S}}><\check{\mathrm{z}}>$, in the orthography of Western and South Slavic languages ${ }^{5}$. Its origin is in the early $15^{\text {th }}$ century Czech orthography attributed to Jan Hus, in which the digraphs previously used for these sounds were replaced by single letters incorporating a diacritic. Over time some, but not all, of the Slavic languages which used the Roman script adopted the haček. According to Rothstein (1977: 225) Polish writers had developed a tradition, based on the German and earlier Czech traditions, of using digraphs rather than diacritics for these phonemes. The Polish printing houses retained and stabilized this tradition by the late sixteenth century, rejecting the use of diacritics (which would have been equally applicable to Polish) because of their association with Hus and his followers, who were viewed as heretics by the Catholic Church (Rothstein 1977: 225). The attribution of the haček to the Protestants thus prevented it from entering Polish orthography. The haček had become a Protestant 'brand ${ }^{6}{ }^{6}$ and the Polish speakers would not touch it.

By the early $19^{\text {th }}$ Century, notwithstanding its Protestant origins, the haček had been introduced to Croatian and Slovenian by Ljudevit Gaj. Remarkably, by virtue of its use in Slovenian, the haček in Austria has become 'an ideologically loaded sign in which different

\footnotetext{
4 'The focus of this line of argument was to show that the Urdu script lacked a perfect relationship between graphemes and phonemes. Hindus further argued that vowels in Urdu are not always marked, which lend Urdu words to multiple readings, which ultimately leads to immense confusion' (Ahmad 2012: 215).

${ }^{5}$ It is also used in Latvian and Lithuanian (non-Slavic) and for foreign loan words in Estonian, Finnish and some other languages.

${ }^{6}$ There are many similar examples in the literature, e.g. according to Magner (2001:18), when Vuk Karadžić reformed the Cyrillic orthography of Serbian in the early $19^{\text {th }}$ Century, by adding (along with five other letters) the letter $\langle\mathrm{j}\rangle$, he 'drew criticism from the Orthodox clergy who regarded it as a "Catholic letter"'.
} 
meanings and connotations intersect', despite the fact that is just a diacritic and has no independent function in the orthography of Slovenian (Busch 2013: 206).

Contrasting visually with German, which has diacritics but no haček, the haček has come to brand Slovenian in the Austrian context: 'in Austria the haček is seen as emblematic for Slavic languages, in Carinthia particularly for the Slovene language. In language ideological discourse it is linked to sounds that are qualified as difficult to pronounce for German speakers, as "tongue twisting” or as "harsh and ugly"' (Busch 2013: 206). This is significant because Carinthia has been a site of linguistic contestation for most of the last century, with the Slovenian-speaking minority contending for language rights in the face of opposition from parts of the German-speaking majority. In this dispute topographical signs in public places have had a central role, with demands for bilingual public signage being a main focus of political activism among the Slovene speakers.

Busch describes two recent lightheartedly ironic campaigns to redefine language relationships in Carinthia, both involving the haček. In one campaign, cultural activists provided a sheet of haček stickers which could be added to German place-name signs, transforming them into something that was strictly speaking neither German nor Slovenian, but where the 'brand' of Slovenian - the haček - was imposed on the German words where it did not belong. 'The addition of the diacritic makes a reference to the forgotten, denied and repressed Slovene language; traces of Slovene are inscribed into the German toponym’ (Busch 2013: 210). Putting it another way, German has been 'rebranded' as Slovene, potentially to the discomfort of users of German.

In another campaign, cultural activists produced 'alphabet soup seasoned and enriched with

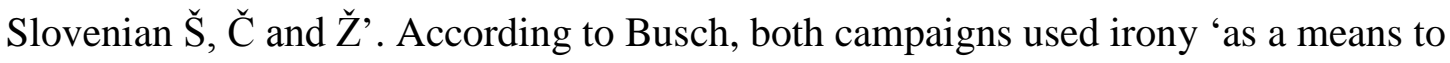
undermine ethnolinguistic categorisations and polarisations’ (Busch 2013: 216); it can be seen that in both, the ability of the haček to brand Slovenian was a key element of the campaign.

\section{Branding and differentiation}

At the same time as branding involves attribution of a graphical feature to a particular group, it implies non-attribution of that feature to other groups. The Slovenes but not the Germans use the haček; the German speakers but not the English speakers use the umlaut. The identity-marking potential of branding is increased when two alternative features, with 
similar functions, come to brand different groups. Steven Bird (2001: 148) gives an example from the Cameroon grasslands languages, where the Bamileke languages use the barred-u symbol $<\boldsymbol{u}>$ for a high central vowel. Other Grassfields languages have the same vowel but write it with $<\dot{\mathbf{i}}>$. Bird writes that 'Bamilekes who are literate in their mother tongue strongly identify with this symbol, which iconifies the strong cultural unity of the group with respect to the languages outside the group’.

A similar case, mentioned by Thomas (2007: 956) involves the Danish characters $<\mathfrak{e}>$ and $<\varnothing>$, which have Swedish counterparts $<\ddot{a}>$ and $<\ddot{o}>$. Historically, this came about because when Sweden separated from Denmark, animosity between the two countries meant that they deliberately adopted different written standards, so that 'the Danish letters $æ$ and $\varnothing$ were rendered as $\ddot{a}$ and $\ddot{o}$ in Swedish—a difference which even today it seems impossible to abolish, because it still serves as an identity marker’ (Vikør 2000: 109).

Just as the existence of a choice of two different 'brands' to provide the same function increases the identity-marking potential, so it also increases the ideological potential of the choice. A good example is the contrast between $<_{\mathrm{c}}>$ and $<\mathrm{k}>$ in the context of the late nineteenth century Philippines (Thomas 2007). A controversial orthographic proposal for Tagalog, a major Phillipine language, was put forward by a group of progressive writers and scholars. Tagalog had for centuries been written using a Spanish-based orthography, where the sound / $\mathrm{k}$ / was represented by $<\mathrm{c}>$ or $<\mathrm{qu}>$ depending on context. This led to anomalies like <cain> "eat" vs. <quinain > "was eaten". In the new orthography, $<\mathrm{k}>$ would represent the initial sound of both. The conservative establishment attacked the orthography, in particular its 'German' letter $<\mathrm{k}>$ (an instance of attribution). The new orthography was proposed publicly and introduced into some progressive publications but it was not widely used. Yet only two years later, in 1892, it was taken up by a secret Philippine revolutionary organisation, as it began the Philippine Revolution against Spanish rule.

The introduction of $<\mathrm{k}>$ was clearly not done lightly, for the name of the revolutionary organisation was Kataastaasan Kagalang-galang na Katipunan ng mga Anak ng Bayan, 'Highest and Most Respectable Society of the Sons of the Country' or just Katipunan. The organisation became widely known by just the initials KKK, which in the then prevailing orthography would have been CCC. Thomas even notes (p. 952) that the organisation seems to have had trouble finding sufficient $k$ 's in fonts of movable type to print their documents, so that they had to 'borrow' $k$ 's from other fonts in order to have enough. This would have been 
a consequence of the rarity of $<\mathrm{k}>$ in Spanish, which meant that typesetters seldom needed it and fonts were provided with small stocks. Despite this the KKK persisted with their orthographic ‘insurrection’ (see Figure 1).

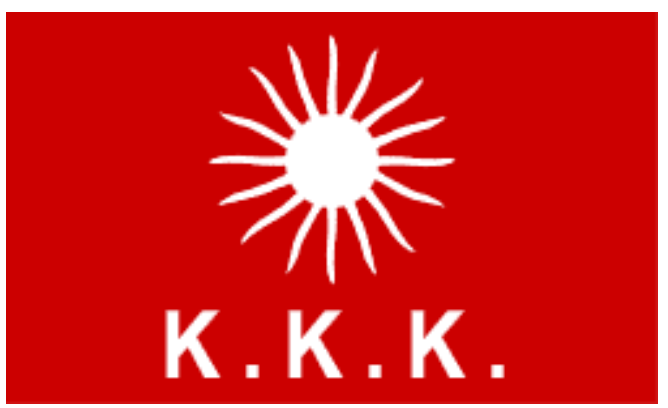

Figure 1: One of the flags of the Philippine KKK (Source: Wikimedia commons, http://commons.wikimedia.org/wiki/File:Philippine_revolution_flag_pugadlawin.png)

That $<\mathrm{k}>$ was able to function as a brand in this way for the KKK is partly due to its ability to contrast with $<_{\mathrm{C}}>$ (and to a lesser extent, with $<\mathrm{qu}>$ ) as a representation of the phoneme $/ \mathrm{k} /$, which occurs in both Spanish and Tagalog. Through this contrast, in addition to serving as a brand for the revolutionary organisation, $<\mathrm{k}>$ could become iconised in opposition to $<\mathrm{c}>/<\mathrm{qu}>$. Where the latter were 'Spanish' and poorly suited to writing Tagalog, which was thereby forced into a Spanish mould which was alien to it, $<\mathrm{k}>$ was ‘not Spanish' and provided a suitable solution for what had previously been a problem in the orthography of Philippine languages. In the same way the colonial government was 'Spanish' and the KKK were 'not Spanish' and offered an alternative government more suited to the Philippine people. So the 'transformation of the relationship' (Irvine and Gal 2000: 37) between the letters and the parties with which they were linked was able to take place, the letters becoming iconic of their user groups ${ }^{7}$. As Thomas puts it:

\footnotetext{
${ }^{7}$ The fact that the wider inventory of the Roman alphabet includes both $<\mathrm{k}>$ and $<\mathrm{C}>$ to represent $/ \mathrm{k} /$, even though some languages use one in preference to the other has made this dichotomy 'ideologically potent' in many different situations. In addition to the cases of Haiti and the Philippines mentioned here, it has been documented in the case of the Spanish counterculture who use $<\mathrm{k}>$ where Castilian has $\langle\mathrm{c}>$ as a branding device (Sebba 2003, 2007, also with illustrations of graffiti), and the Basque youth counterculture where likewise $<\mathrm{k}>$ is used subversively to make Spanish look like Basque (Urla 1995). It is also socially meaningful in the context of Dutch in the Netherlands and Belgium (Geerts et al. 1977; see Sebba 2012 for an overview).
} 
the banner of the letter " $k$ " might be taken to indicate the way that the distinctiveness of the language - its difference from Spanish — was part of the claim of the revolutionaries to selfrule. We have our own language; we should have our own government. (Thomas 2007: 955)

\section{Branding and visual salience}

As mentioned in the introduction, the visual nature of scripts means that each element of a script - whether a letter, a logogram, or even a component of a character - must have an associated image. It is these images which allow graphic branding to take place, and which give individual orthographies a characteristic 'look'. This 'look' clearly is perceived by users of the language, who - as many examples in the literature have shown - may react negatively to attempts to change it. Various researchers have mentioned this, for example Schieffelin and Doucet (1994: 191) describe the negative response to the "Anglo-Saxon look" given to Haitian Creole by the letters $\langle\mathrm{w}\rangle,\langle\mathrm{k}\rangle$, and $\langle\mathrm{y}\rangle$, while Thomas stresses the importance of the visual distinctiveness of $<\mathrm{k}>$ from $<\mathrm{c}>$ in the case of Tagalog:

[...] that the Katipunan did adopt the letter " $k$ " and that they used it emblematically suggests that the imagery or visual difference from written Spanish might have been part of the reason it was adopted. While the " $k$ " may well have been embraced by this revolutionary organization for its pedagogical benefits, its use as an emblem exploited its symbolic significance. That the letter " $k$ " appeared on the flags of the revolutionary society highlights one of the functions of orthography: that of signifying, or "flagging," the nation. (Thomas 2007: 954, footnote omitted)

The visual elements of a language are of course not confined only to the pages of books and written documents which are mainly intended for readers of the language concerned. They may also be part of the linguistic landscape ${ }^{8}$, “the visibility and salience of languages on public and commercial signs” (Landry and Bourhis 1997: 23) and this might further be extended to include texts on objects in everyday use among the public such as stamps, banknotes, tickets and timetables (Sebba 2010). The presence of texts on such common items, often in visually salient forms and positions, may give their users - even those who cannot read the languages concerned - an impression of their written appearance. Thus the 'look' of a language is also perceivable to some extent by non-users, who may be aware of particular differences from their own practice (for example, the use of umlauts, cedillas or strokes) or of

\footnotetext{
${ }^{8}$ For an overview of research on Linguistic Landscapes, see Gorter 2013.
} 
more general properties of a script, such as the shape of strokes, ligatures or ascenders. It is the latter kind of awareness which makes possible the phenomenon of faux fonts, fonts designed to resemble scripts for other languages, as in figure 2, which shows the shop sign of a restaurant in England. The restaurant name is Chandini, "moonlight” in Hindi, and written in the Roman alphabet but in a font designed to resemble the Devanagari script used to write Hindi ${ }^{9}$. Although probably most of the passers-by do not know how to read Hindi, they may recognise some features of Hindi script, such as the horizontal bar above the letters, the characteristic curves of the letters and the short strokes above the bar. In this case - as is quite widespread in the food industry - the graphical features of the faux font are used to mark the logo as 'Indian' and thereby indicate that the restaurant specialises in Indian food.

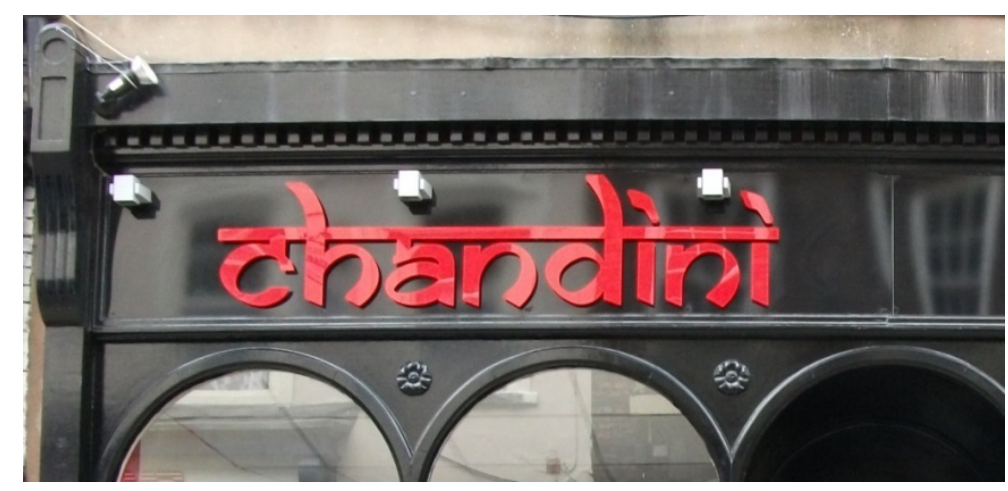

Figure one: Faux 'Hindi’ font Indian Restaurant logo Source: author

The point being made here is that visual features of writing can be used to index a group (to whom the writing is attributed) even for those who do not know the language, or script, in question. This allows for the possibility of using distinctive elements of orthographies as a brand, 'flagging the nation' as Thomas puts it ${ }^{10}$. An example is provided by the banknotes of the post-USSR state of Azerbaijan. After the breakup of the USSR, Azerbaijan became an independent state with Azerbaijani (a Turkic language) as its official language. Scripts have been an area of contention in Azerbaijan for most of the last century and in that time there have been three changes of script, from Perso-Arabic to Roman, from Roman to Cyrillic, and - most recently - from Cyrillic to Roman again. Azerbaijan has used its banknotes as a way of celebrating the reintroduction of Roman script ${ }^{11}$. The 5 manat banknote (figure 3 shows the obverse) is dedicated to cultural themes, and several of the 'new' letters have been

\footnotetext{
${ }^{9}$ The Hindi word is written चांदनी in Devanagari script.

${ }^{10}$ Thomas uses 'flagging' in the sense of Billig (1995).

${ }^{11}$ For a discussion of the role of banknotes in 'flagging the nation' see Penrose (2011).
} 
foregrounded in the design - but not just any letters. They are precisely the letters which distinguish Azerbaijani from most, possibly all, other languages which use Roman letters: $<$ ə $>,<$ ş $>,<\breve{\mathrm{g}}>$ and (less significantly) $<\ddot{0}>$. Most prominent in the design is $<\boldsymbol{\vartheta}>$, which sets Azerbaijani apart from its close relative Turkish, which uses $<$ ş>, $<\breve{\mathrm{g}}>$ and $<\ddot{\mathrm{o}}>$ in its orthography, but not $<$ ə> . It is also the third letter in the country’s name, Azarbaycan. While these letters of course are linguistically significant for speakers of Azerbaijani, it is their visual salience which provides the rationale for putting them on the banknote. They look different, and make Azerbaijani look different, even though Azerbaijani now uses the 'same' alphabet as most Western European languages ${ }^{12}$ (See Hatcher 2008 for an account of the relationship between script and identity in Azerbaijan. Also Sebba 2006 for an analogous case in Tatarstan).

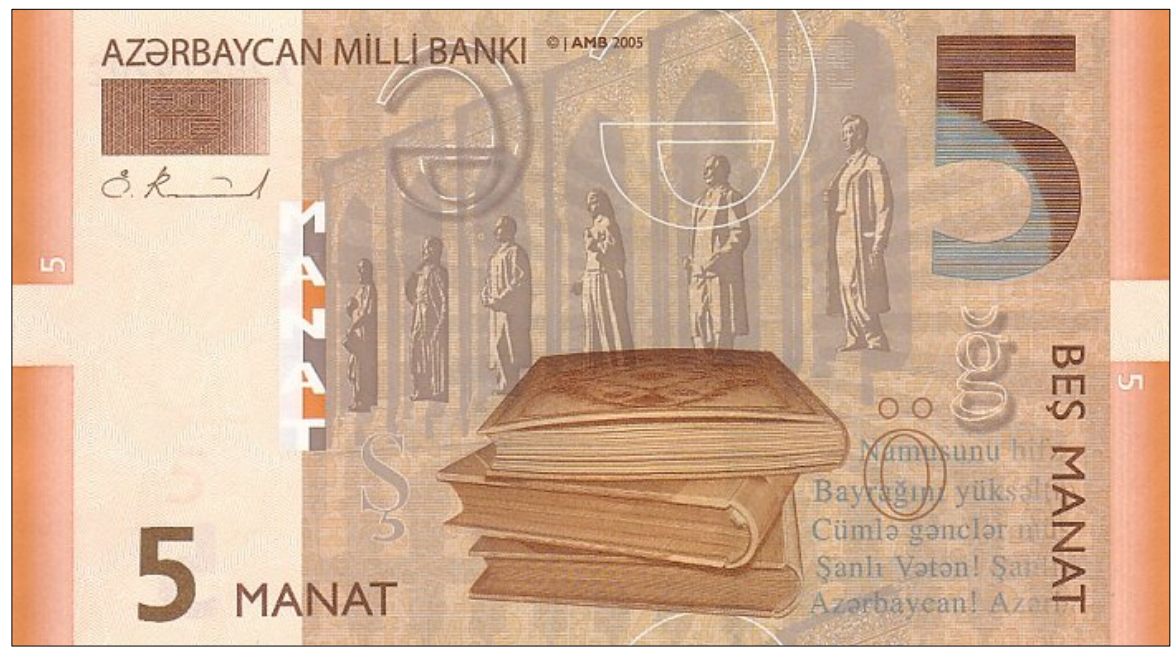

Figure 3: Azerbaijan 5 Manat, 2005. Source: Wikimedia commons http://en.wikipedia.org/wiki/File:5_manat_obv.jpg

While the orthographic branding illustrated on the Azerbaijan five manat note may be intended for Azerbaijanis or non-Azerbaijanis, there are some clear examples of 'distinctive' characters being used to brand products in foreign countries where the characters in question are not used. The importance of $<\emptyset>$ in Danish as a mark of distinctiveness from Swedish has

\footnotetext{
${ }^{12}$ A more localised, institutional example of orthographic branding is the logo of Heritage Malta, a national agency with responsibility for museums and other heritage sites in Malta. It uses an image of the capital letter $<\mathrm{H}>$ (Unicode Character 'Latin Capital Letter $\mathrm{H}$ With Stroke') as its logo (see http://heritagemalta.org/). No doubt the reason for this choice of letter is that Maltese is one of the very few languages that use it as part of the normal orthography of the language. However, it is a different letter from $<\mathrm{H}>$ in Maltese, and is not the first letter of the word for heritage in English or Maltese.
} 
already been mentioned. However, it appears that this letter (which is also used in Norwegian and Faroese, but not in any other languages) has value as a 'brand marker' of Nordicness even in English-speaking countries, where it is not used in the orthography. An American furniture chain used it as branding in its name STØR in the 1990s, apparently to index the Scandinavian style of its furniture; it was sued for copyright infringement - and then bought by the Swedish company IKEA. STØR was later parodied as SHØP in The Simpsons animated series.

We might wonder how the letter $<\emptyset>$ - rarely seen outside its Scandinavian homeland - has come to signal graphic Nordicness to an English-speaking public (most of whom presumably are not sure how to pronounce it even if they can recognise it). Yet it seems that $\langle\emptyset>$ is recognizable enough to be used for commercial orthographic branding, as shown by the case of STØR. More recently at least one company has used $\langle\emptyset\rangle$ as a playful marketing tool targeted at English-speaking consumers: around 2007 the British food producer Tulip ran a high-profile advertising campaign for its Danepak range of Danish-sourced pork products with the slogan FRØM THE FAMILY FARMS ØF DENMARK.

\section{Branding and iconisation in the globalised economy: a Danish case study}

Some recent events in Denmark have highlighted the relevance of orthographic branding in both the local and the global economy. The alphabetic inventory of Danish contains the letter $<\AA ̊$ (lower case: $<\mathrm{a}>$ ), which is also found in other Nordic languages and a few others. While the letter itself was in use much earlier in the Scandinavian languages, it was only adopted officially as part of the Danish alphabet in 1948, to replace the sequence <aa>. In the current official orthography, $<a ̊$ is the correct form to use in Danish-origin words which are not proper names. In the case of personal names, which variant to use is the prerogative of the person whose name it is; in the case of place names, municipalities may choose their preferred spelling, but it is never incorrect to use $<\mathrm{a}>$ (Danish Language Board, n.d.). Thus although the town of Aabenraa prefers the double-a spelling for its name, it would not be wrong to use the form recommended by the Danish Language Board, Åbenrå. ${ }^{13}$

\footnotetext{
${ }^{13}$ According to the Wikipedia article on Aabenraa, the Danish spelling reform of 1948 was highly controversial in the town, because the new recommended spelling for the town's name would mean that instead of occupying the first place in an alphabetic list of places, it would now be near the end (as $<\stackrel{\mathrm{a}}{>}$ is the last letter in the Danish alphabet).

Source: http://en.wikipedia.org/wiki/Aabenraa and http://da.wikipedia.org/wiki/Aabenraa, accessed $19^{\text {th }}$ March 2014 .
} 
In recent years, controversy has arisen in Denmark over the spelling of city names containing $<\mathrm{a}>{ }^{14}$. In 2010 Nikolaj Wammen, the mayor of Århus, the second largest city in Denmark, gained majority support in the city council for changing the spelling of the city's name back to its pre-1948 spelling Aarhus. Although allowed under the official spelling rules, this is not the form recommended by the Danish Language Board. The mayor is reported to have said on television that the reasons for preferring $<\mathrm{Aa}>$ were (1) that $<\mathrm{Aa}>$ is more beautiful than $<\AA>$; (2) that $<\mathrm{Aa}>$ is more historically correct $^{15}$; (3) that $<\mathrm{Aa}>$ is more international than $<\AA>$ because $<\AA>$ is a character which is difficult to use on the internet (Grandt n.d.).

Whatever the merits of the first two points, it is clear that debate has mainly been concerned with the issue of visibility in the global economy. Wammen made this explicit when he told the press ‘the debate shouldn't be about cost - it should be about how we best brand Århus internationally' (Copenhagen Post 2011). A spokesman for the mayor was quoted as saying that any costs would be recovered in the form of increased publicity and more tourist revenue (Ekstra Bladet 2010).

Proponents of the $<\mathrm{Aa}>$ spelling uphold the notion that a 'special' character is unhelpful in a globalized world. The rector of Aarhus University is quoted as saying 'it creates unnecessary confusion for communication when a city name is spelled with a special Danish symbol' (Copenhagen Post 2011). The Århus chamber of commerce is reported to be behind the change for the same reason. A firm of international marketing consultations is quoted as saying that 'the spelling will not change the city's inevitable expansion, but it makes us more aware that there is a world out there that we need to communicate with, and that we have to use aa' (Jyllands-Posten 2010). A television show host is reported (Grandt n.d.) to have

\footnotetext{
${ }^{14}$ The following discussion is based on an internet search for web sites, blogs and news media reports in connection with the spelling change for the name of Aarhus/Århus. The search took place in early 2014, some time after the peak of the controversy. No claims are made for exhaustiveness, or the representativeness of the views.

${ }^{15}$ The fact that the spelling Århus dates from 1948 has made it possible for advocates of both $<\mathrm{Aa}>$ and $<\AA>$ to claim that their preferred spelling has the benefit of having been established for generations, although less so in the case of $<\AA>$. In this case the mayor was reported to have said that the spelling Aarhus was 'rooted in the city's history, in our souls , in our DNA' (Grandt n.d.) A city hall spokesman was quoted as saying 'the name of Aarhus will both point backwards into our history and into the future' (Ekstra Bladet 14 March 2010).
} 
called the $<$ Aa $>$ spelling 'modern', again linking it to globalization, viewed as positive change.

The $<\mathfrak{a}>$ spelling has its supporters, however. The newspaper Jyllands-Posten reported an expert from a brand and design agency as recommending the city to retain the $<a ̊$ spelling 'because the å is unique to Denmark, and has identity and something exotic about it. Right now there is a demand for authenticity and the original thing' (Jyllands-Posten 2010). He continued: 'it helps to provide spice and charm and it clearly shows Danish heritage and that Aarhus is a place where we can offer something different.' In the same article, a professor of marketing at the University is quoted as saying that 'it may be easier to get noticed if one has funny letters [sjove bogstaver] in one’s name. You could argue that keeping å creates more visibility, also because there is more local authenticity in it - especially for foreigners'.

Opponents of the $<\mathrm{Aa}>$ spelling also see the reversion to $<\mathrm{aa}>$ as submitting to the international dominance of English. A former chairman of the Danish Language Board is quoted (Copenhagen Post 2011) as believing that the spelling controversy is really part of a wider debate about the importance of English, and that 'the tendency to accommodate the English-speaking world weakens the Danish language’. Proponents of $<\mathrm{a}>$ support it precisely because of its Danishness: 'One sometimes hears the argument that foreigners don't know the Danish a and that therefore it's better to use $a a$. That's a bad argument. Should we also [change the spelling of Danish words with $\langle\emptyset>$ ] simply because some foreigners use a different alphabet from the Danish?’ (Bevar bolle-å'et i danske stednavne! n.d.)

This debate shows, among other things, how the potential for distinctive characters of the orthography to act as a brand is increased when they occur in particularly salient or culturally significant words: in this case city names. In the case of Aarhus and Aabenraa, that potential is increased even further by the fact that the character in question is the initial letter of the place name, bringing with it additional functions (with risks and benefits) such as the use in acronyms and in alphabetical ordering ${ }^{16}$.

In the $<\mathrm{a}>/<$ aa $>$ place name debate, we see the discursive emergence of attribution, in the association of different practices with different groups. We see, too, the emergence of branding - the emblematic use of $<a ̊$ and $<$ aa $>$ in the maximally salient context of the first letter of the city name, with $<\grave{a}>$ being put forward explicitly as a 'brand' for Århus. We can

${ }^{16}$ The same can be said of the salience of $<\mathrm{k}>$ in the case of the Katipunan described above. 
see also the potential path to iconisation, as the 'funny letter' $<a ̊$ is proposed as a way not only to get noticed, but also as a mark of 'a place where we can offer something different'. In this case the debate is not yet over, the arguments are still being made and we cannot yet say that a 'transformation has taken place' in the relationship between $<\mathrm{a}>$ and 'the social image with which it is linked' (Irvine and Gal 2000: 37), but such a change could take place if the spelling <Århus $>$ wins the day.

\section{Conclusions}

The concept of 'iconisation' is a valuable one which has been taken up enthusiastically by researchers in the area of orthography. However, the visual nature of scripts means that iconicity can be interpreted rather literally (in the sense of a graphic image) or in the more metaphorical sense in which it is used by Irvine and Gal. By distinguishing iconisation from two related processes, called in this paper attribution and branding (of which the latter specifically applies to orthographies), I have tried to clarify the different ways in which orthographic elements can function as markers of identity and differentiation. Branding involves the selection of a specific salient element of the writing system as emblematic of its users: hence anything that adds to the salience of an orthographic element, such as being the first character in the name of a city or organisation, will increase its branding potential. The existence of alternative items with similar function will increase the potential for each variant to brand a different group; this in turn increases the potential for iconisation, where attributes such as foreignness, deviance, authenticity and modernity can be associated not just with the variant linguistic forms but also with the groups who are constructed as using them.

In all of this, the discursive construction of knowledge about language and language users has a central role. Spitzmüller (2012: 261-262) points out that 'whether graphic elements are perceived as being 'foreign' or not [...] depends on the graphic knowledge of the actors' including the contextual setting in which they were first met'. More generally, the associations that are made with particular elements of orthography are partly a matter of individual experience, and partly a matter of collective (and thus discursively produced) knowledge. Because such experiences and knowledge are contingent on the linguistic and historical context, it means that the same orthographic element can be used to brand different things: the $<\mathrm{k}>$ can be a brand for the Philippine revolutionaries in one situation, and for Basque language activists in another. The haček likewise could brand Protestantism for the Poles but Slavicness for German-speaking Austrians. 
The visual and graphical aspects of branding and iconisation seem to warrant further research. Such research would be in keeping with the current visual or multimodal turn in the social sciences, which has also influenced the field of linguistics. More insight into the role of visual distinctiveness in writing systems would help us to a better understanding of what has the potential to brand, and what becomes iconic and why.

\section{References}

Agha, Asif (2007). Language and Social Relations. Cambridge, Cambridge University Press.

Ahmad, Rizwan (2012). Hindi is perfect, Urdu is messy: the discourse of delegitimation of Urdu in India. In A. Jaffe et al. (eds), 103-133. Originally published as 'Scripting a new identity: the battle for Devanagari in $19^{\text {th }}$ century India'. Journal of Pragmatics 40 (2008): 1163-1183.

Androutsopoulos, Jannis (2010). Ideologizing ethnolectal German. Sally Johnson \& Tommaso M. Milani (eds.), Language ideologies and media discourse, 182-202. New York: Continuum.

Bevar bolle-å'et i danske stednavne! (n.d.). 'Keep a-ring in Danish place names!' http://www.jeppesn.dk/aa-galskab.html, retrieved on $24^{\text {th }}$ March 2014.

Billig, Michael (1995). Banal nationalism. London: Sage Publications.

Bird, Steven (2001). Orthography and identity in Cameroon. Written Language and Literacy 4 (2): 131-162.

Busch, Brigitta (2013). The career of a diacritical sign: Language in spatial representations and representational spaces. In Sari Pietikainen \& Helen Kelly-Holmes (eds.), Multilingualism and the periphery, 199-221. Oxford: Oxford University Press.

Copenhagen Post (2011). ‘Århus mayor prefers Aarhus: Supporters of eliminating the Danish spelling of Århus believe the $\AA$ is a hindrance in international communication’. Copenhagen Post, 15 March 2011. Retrieved from http://cphpost.dk/news/aarhus-mayor-prefersaarhus.133.html, on 20th March 2014.

Danish Language Board (n.d.). ‘§ 3. Å og dobbelt-a’ ( $\AA$ and double-a, subsection of 
orthographic rules). Retrieved from http://sproget.dk/raad-ogregler/retskrivningsregler/retskrivningsregler/a7-1-6/a7-3-a-og-dobbelt-a, on 20th March 2014.

Davies, Eirlys E. (1987). Eyeplay: on some uses of nonstandard spelling. Language and Communication 7 (1): 47-58.

Ekstra Bladet (2010). 'Århus vil droppe bolle-Å'et' ('Aarhus wants to drop the Å-ring’). Ekstra Bladet (Copenhagen) 14 March 2010Retrieved from ttp://ekstrabladet.dk/nyheder/politik/article1313860.ece on 24th March 2014.

Geerts, Guido, Jef Van Den Broeck \& Albert Verdoodt (1977). Successes and failures in Dutch Spelling Reform, In Joshua A. Fishman (ed.), Advances in the creation and revision of writing systems, 179-245. The Hague: Mouton.

Gorter, Durk (2013). Linguistic landscapes in a multilingual world. Annual Review of Applied Linguistics 33: 190-212.

Grandt, Jørgen (n.d.). ‘Århus bør altid staves med Å!’ http://www.grandts.dk/Aarhus/aarhusbolle.htm retrieved 20th March 2014.

Hockett, Charles F. (1966). The problem of universals in language. In J. Greenberg (ed.), Universals of Language, pp. 1-29. Cambridge, MA: The MIT Press

Hatcher, Lynley (2008). Script change in Azerbaijan: acts of identity. International Journal of the Sociology of Language 192: 105-116.

Irvine, Judith T. \& Susan Gal (2000). Language ideology and linguistic differentiation. In Paul V. Kroskrity (ed.), Regimes of language: Ideologies, polities and identities, 35-83. Oxford: James Currey.

Jaffe, Alexandra, Jannis Androutsopoulos, Mark Sebba \& Sally Johnson (eds.) (2012). Orthography as social action: Scripts, spelling, identity and power. Berlin: Mouton de Gruyter.

Johnson, Sally (2005). Spelling trouble. Language, ideology and the reform of German orthography. Clevedon: Multilingual Matters. 
Jyllands-Posten 2010. 'Eksperter: Bolle-å giver synlighed’ ('Experts: A-ring gives visibility'). Jyllands-Posten, 16.03.2010. Retrieved from http://jyllandsposten.dk/aarhus/politik/ECE4995050/eksperter-bolle-a-giver-synlighed?page=1 on 24th March 2014.

Landry, Rodrigue \& Richard Y. Bourhis (1997). Linguistic landscape and ethnolinguistic vitality: An empirical study. Journal of Language and Social Psychology 16: 23-49.

Le Page, Robert B. \& Andrée Tabouret-Keller (1985). Acts of identity. Creole-based approaches to language and ethnicity. Cambridge: Cambridge University Press.

Magner, Thomas F. (2001). 'Digraphia in the territories of the Croats and Serbs'. International Journal of the Sociology of Language 150: 11-26

Penrose, Jan (2011). Designing the nation. Banknotes, banal nationalism and alternative conceptions of the state. Political Geography 30 (8), 429-440

Preston, Dennis R. \& Nancy A. Niedzielski (2000). Folk linguistics. Trends in linguistics. Berlin and New York: Mouton De Gruyter.

Rothstein, Robert A. (1977). Spelling and society: the polish orthographic controversy of the 1930’s, In Benjamin A. Stolz (ed.), Papers in Slavic Philology I, 225-236. Ann Arbor: Dept. of Slavic Languages and Literatures, University of Michigan.

Schieffelin, Bambi B. \& Rachelle C. Doucet (1994). The "real" Haitian Creole: ideology, metalingusitics and orthographic choice. American Ethnologist 21: 176-200.

Sebba, Mark (2003). Spelling rebellion. In Jannis Androutsopoulos \& Alexandra Georgakopoulou (eds.), Discourse constructions of youth identities, 151-172. Amsterdam: John Benjamins.

Sebba, Mark (2006). Ideology and alphabets in the former USSR. Language Problems and Language Planning 30 (2), 99-125.

Sebba, Mark (2007). Spelling and society: The culture and politics of orthography around the world. Cambridge: Cambridge University Press. 
Sebba, Mark (2010). Discourses in transit. In Adam Jaworski \& Crispin Thurlow (eds.), Semiotic landscapes: Language, image, space, 59-76. London: Continuum.

Sebba, Mark (2012). Introduction: Orthography as social action. In Alexandra Jaffe et al., 120.

Spitzmüller, Jürgen (2007). Graphisches Crossing. Eine soziolinguistische Analyse graphostilistischer Variation. In: Zeitschrift für Germanistische Linguistik 35 (3), 397-418.

Spitzmüller, Jürgen (2012). Floating ideologies: Metamorphoses of graphic “Germanness”. In Alexandra Jaffe et al., 255-288.

Thomas, Megan C. (2007). K is for de-kolonization: Anti-colonial nationalism and orthographic reform. Comparative Studies in Society and History 49: 938-967.

Urla, Jacqueline (1995). Outlaw language: Creating alternative public spheres in Basque Free Radio. Pragmatics 5 (2): 245-61. Reprinted in Roxy Harris \& Ben Rampton (eds.) (2003) The language, ethnicity, and race reader, 211-224. London: Routledge.

Vikør, Lars S. (2000). Northern Europe: Languages as prime markers of ethnic and national identity. In Stephen Barbour \& Cathie Carmichael (eds.), Language and nationalism in Europe. Oxford: Oxford University Press, 105-29.

Vosters, Rik, Gijsbert Rutten, Marijke van der Wal \& Wim Vandenbussche (2012). Spelling and identity in the Southern Netherlands (1750-1830). In Alexandra Jaffe et al., 135-159. 